\title{
RESEARCH
}

\section{Regional Assignment of 68 New Human Gene Transcripts on Chromosome 11}

\author{
Marie-Françoise Rosier, ${ }^{1,2,4}$ Isabelle Reguigne-Arnould, ${ }^{2,3}$ \\ Philippe Couillin, ${ }^{3}$ Marie-Dominique Devignes, ${ }^{1}$ and Charles Auffray ${ }^{1,2}$
}

\author{
${ }^{1}$ Genexpress, Centre National de la Recherche Scientifique (CNRS UPR420), Villejuif CEDEX, France; \\ ${ }^{2}$ Genexpress, Généthon, Evry, France; ${ }^{3}$ Institut National de la Santé et de la Recherche Médicale \\ (INSERM U178), Villejuif CEDEX, France
}

\begin{abstract}
We have tested 80 expressed sequence-tagged site (eSTS) markers assigned to human chromosome 11 by the Genexpress program on a panel of somatic cell hybrids containing parts of this chromosome, characterized by cytogenetic data, reference markers, and with respect to the Généthon microsatellite genetic map. Sixty-eight new gene transcripts have been assigned to 25 subregions, one of which was newly defined by five of the eSTS markers. The markers are distributed on the short and long arms in agreement with their physical length. The genic map thus obtained has been integrated with the cytogenetic, genetic, and disease maps. Two eSTS markers have been further mapped with respect to a yeast artificial chromosome (YAC) contig close to the brain-derived neurotrophic factor (BDNF) gene and thus provide potential candidate genes for the mental retardation phenotype of WAGR (Wilms' tumor, aniridia, genitourinary abnormalities and mental retardation) syndrome. Altogether, the 68 new gene transcripts localized here represent more than a threefold increase in the number of unknown regionalized genes that could reveal potential candidate genes for the numerous orphan pathologies associated with chromosome 11.
\end{abstract}

Identification of the genes responsible for human genetic disorders is a major goal of the human genome project. The availability of a high resolution genetic map based on microsatellite markers provides a basis for the positional cloning efforts and the integration of the physical map based on ordered contigs of cloned DNA fragments (Gyapay et al. 1994; Murray 1994). Once an interval of several hundred kilobases to several megabases is identified, it is necessary to catalog all of the genes in this interval and identify to one that is mutated in relation to the disease. This is usually performed by direct testing of candidate genes that have been previously characterized and mapped to the interval, or by direct selection, exon amplification, or exon trapping methods to characterize new genes (for review, see Gardiner and Mural 1995)

Sequencing of cDNA clones has allowed the characterization by structural data of a large fraction of all human gene transcripts. This provides

\footnotetext{
${ }^{4}$ Corresponding author.

E-MAll devignes@genome.vjf.inserm.fr; FAX 33-1-49-58-35

09.
}

a basis to develop expressed STS markers (eSTS; Auffray et al. 1995) that can be used to build a genic map of the human genome and integrate it with the genetic and physical maps. Thus, in addition to the 3700 genes registered previously in the Genome Data Base (GDB), the Genexpress, and other programs (Polymeropoulos et al. 1993; Auffray et al. 1995 and references therein) have recently developed $>4000$ new eSTS markers and assigned them to specific chromosomes using panels of human-rodent somatic cell hybrids containing one or a limited number of human chromosomes. Based on the collection of 2801 eSTS markers developed by the Genexpress program, we have undertaken the building of a genic map of the human genome in collaboration with laboratories participating in the IMAGE Consortium. Regional assignment can proceed using collections of somatic cell hybrids defining breakpoint or rearrangements along one chromosome, providing a resolution in the range of 1 to several $\mathrm{Mb}$ (Couillin et al. 1994; Withmore et al. 1994). Positioning in a genetic map interval is rarely obtained directly when the marker is not polymorphic, and in most cases is obtained indirectly us- 
HUMAN CHROMOSOME 11 NEW GENE TRANSCRIPIS

ing resources such as radiation hybrid panels (Cox et al. 1990; James et al. 1994). The definition of clones containing the corresponding gene and integrated in the physical map provides the tool for further studies at the genomic level. Although the availability of eSTs markers assigned to a given interval represents an attractive resource for the establishment of the expression maps aimed at identifying genes responsible for genetic disorders (Chiannilkulchai et al. 1995).

Here we describe a contribution to the genic map of chromosome 11 based on a panel of somatic cell hybrids. This chromosome represents $\sim 4.8 \%$ of the human genome and extends over $\sim 144 \mathrm{Mb}$ (Morton 1991). It should therefore encode $\sim 2800-3500$ of the estimated $60,000-80,000$ genes believed to represent the coding capacity of the human genome (Antequera and Bird; Fields et al. 1994). To date, 202 identified genes have been localized on chromosome 11 as well as 29 transcribed sequences (van Heyningen and Little 1995; GDB). Sixty-nine diseases are linked to chromosome 11 and for 31 of them no responsible gene has been identified so far. These diseases will be considered here as "orphan pathologies" by analogy with orphan receptors, which lack identified ligands. They include BeckwithWiedemann syndrome, long QT syndrome, hypertrophic cardiomyopathy 4, Bardet-Biedl syndrome, and part of a complex pathology, the WAGR syndrome (Wilms tumor, aniridia, genitourinary abnormalities and mental retardation). We tested for the presence of 80 eSTS markers assigned to chromosome 11 by the Genexpress program on DNA from a panel of 25 somatic cell hybrids bearing different rearrangements of human chromosome 11 that delineate 24 subregions. These subregions have been characterized previously with respect to their microsatellite marker content (Couillin et al. 1994; S. Fauré and J. Weissenbach, pers. comm.).

In addition, we used the data of the so created genic map to study the genetic context of the human brain-derived neurotrophic factor (BDNF) gene localized at 11p13 (Maisonpierre et al. 1991). Deletion of the BDNF gene has been shown to correlate with the severity of the mental retardation phenotype of the WAGR syndrome that maps in the $11 \mathrm{p} 13$ region (Hanson et al. 1992). The presence of two eSTS markers in the corresponding subregions was tested on a 1.7$\mathrm{Mb}$ yeast artificial chromosome (YAC) contig constructed around the BDNF gene (Rosier et al. 1994). One eSTS corresponding to an as yet un- known transcript was localized on the BDNF YAC contig and represents a potential candidate gene for the mental retardation phenotype.

The 70 gene transcripts newly localized in particular subregions define potential candidate genes for the 31 orphan pathologies associated with chromosome 11.

\section{RESULTS}

\section{Description of the eSTS Markers}

The ESTS markers used in this study are from the collection established at Généthon by the Genexpress program and assigned to chromosome 11 (Auffray et al 1995). These eSTS markers have been derived from selected partial cDNA sequences established upon the sequencing of two cDNA libraries constructed from skeletal muscle and infant brain mRNA. The GDB D numbers of the 80 eSTS markers studied here are listed in Table 1 . In the case of multiassignments (8/80 eSTS markers, corresponding to pseudogenes or gene families), only the $D$ number corresponding to chromosome 11 is indicated. The cDNA clone (name and sequence accession number in the EMBL data base) from which eSTS markers are derived are indicated, as well as any similarity to other known sequences. Detailed sequence analysis will be described elsewhere (R. Houlgatte, R. Marriage-Samson, S. Duprat, A. Tessier, S. Bentolila, B. Lamy, and C. Auffray, in prep.). Most eSTS markers $(69 / 80)$ have been designed from cDNA sequences that did not match any known sequence (no identity). Among these, nine cDNA clones have been classified in four distinct families according to internal sequence similarities ( $R$. Houlgatte et al., in prep.). They are indicated by numbers in Table 1 . Seven eSTS markers correspond to known gene transcripts (id in Table 1) of which five (D11S2241E, D11S2242E, D11S2244E, D11S2245E, and D11F194S1E corresponding to ACAT1, CRYAB, SRPR, NDUFV1, and $\mathrm{HBB}$, respectively) had already been assigned to a precise location on chromosome 11 . They serve as controls for our regionalization procedure. The sixth and seventh eSTS markers corresponding to the transcripts for acidic ribosomal phosphoprotein P2 and small nuclear ribonucleotide polypeptide $\mathrm{C}$, respectively, had not been mapped previously. Finally, four eSTS markers correspond to transcripts with similarities with known sequences. D11S2269E and D11S2274E correspond to sequences homologous to mouse flap endonuclease-1 and rat LL5 protein, respectively; 
ROSIER ET AL.

Table 1. List of eSTS markers used in this study

\begin{tabular}{|c|c|c|c|c|c|c|}
\hline $\begin{array}{l}\text { eSTS } \\
\text { D numbers }\end{array}$ & $\begin{array}{l}\text { Chromosome } \\
\text { assignment }\end{array}$ & $\begin{array}{l}\text { Corre- } \\
\text { sponding } \\
\text { cDNA } \\
\text { clones }^{b}\end{array}$ & $\begin{array}{l}\text { EMBL } \\
\text { sequence } \\
\text { accession } \\
\text { number }\end{array}$ & Status ${ }^{c}$ & Gene product & Subregions \\
\hline $\begin{array}{l}\text { cdyObh07 } \\
\text { (submitted) }\end{array}$ & 11 & c-0bh07 & F05464 & id & $\begin{array}{l}\text { small nuclear } \\
\text { ribonucleotide } \\
\text { polypeptide C }\end{array}$ & 21 \\
\hline D11S2227E & 11 & b- $14 \mathrm{~g} 12$ & Z19327 & no id & & 22 \\
\hline $\mathrm{D} 11 \mathrm{~S} 2228 \mathrm{E}$ & 11 & b-30a01 & $Z 28525$ & no id & & 22 \\
\hline D11S2229E & 11 & b-31a10 & Z28534 & no id & & 10 \\
\hline D11S2230E & 11 & b-63a06 & Z28611 & no id & & 22 \\
\hline D11S2231E & 11 & b-72c08 & Z28653 & no id & & 22 \\
\hline $\mathrm{D} 11 \mathrm{~S} 2232 \mathrm{E}$ & 11 & b-73g08 & F00203 & no id & & 21 \\
\hline D11S2233E & 11 & $\mathrm{~b}-80 \mathrm{e} 02$ & F00215 & no id & & 20 \\
\hline D11S2235E & 11 & b-84a05 & Z28721 & no id & & 20 \\
\hline D11S2236E & 11 & b-93d06 & $\mathrm{Z} 28772$ & no id & & 24 \\
\hline D11S2238E & 11 & b-99d07 & F00394 & no id & & 20 \\
\hline D11S2239E & 11 & b-b6c05 & Z28895 & no id & & 20 \\
\hline D11S2240E & 11 & b-c1a09 & Z28919 & no id & & 20 \\
\hline D11S2241E & 11 & b-06d09 & F00504 & id & $\begin{array}{l}\text { mitochondrial } \\
\text { acetoacetyl-CoA } \\
\text { thiolase }\end{array}$ & 22 \\
\hline D11S2242E & 11 & b-17g01 & F00595 & id & docking protein alpha & 24 \\
\hline D11S2243E & 11 & b-30e05 & F00674 & id & $\begin{array}{l}\text { acidic ribosomal } \\
\text { phosphoprotein P2 }\end{array}$ & 1 \\
\hline D11S2244E & 11 & b-32d09 & F00690 & id & alpha B-crystallin & 22 \\
\hline D11S2245E & 11 & b-34h10 & F00706 & id & $\begin{array}{l}\text { human NADH } \\
\text { dehydrogenase } \\
\text { (ubiquinone } \\
\text { flavoprotein } 1 \text { (51 } \\
\text { kD) }\end{array}$ & 19 \\
\hline D11S2246E & 11 & b-48d01 & F00755 & no id & & 22 \\
\hline D11S2247E & 11 & b-48e02 & Z24835 & no id & & 3 \\
\hline D11S2248E & 11 & b-57g10 & Z24847 & no id & & 18 \\
\hline D11S2249E & 11 & b-63c08 & Z24869 & no id & & 20 \\
\hline D11S2250E & 11 & b-71e04 & Z28648 & no id & & 24 \\
\hline D11S2251E & 11 & b-71g02 & F00845 & no id & & 22 \\
\hline D11S2252E & 11 & $b-80 f 06$ & Z24987 & no id & & 3 or 15 \\
\hline D11S2255E & 11 & $c-02 b 04$ & Z38186 & no id & & 20 \\
\hline $\mathrm{D}_{11 \mathrm{~S} 2256 \mathrm{E}^{1}}$ & 11 & $\mathrm{c}-02 \mathrm{~h} 07$ & F01414 & no id & & 19 \\
\hline D11S2257E & 11 & c-0af02 & Z38414 & no id & & $\begin{array}{l}1,2,3,15 \\
\text { or } 16\end{array}$ \\
\hline $\mathrm{D} 11 \mathrm{~S} 2258 \mathrm{E}^{2}$ & 11 & $c-0 c c 01$ & F01735 & no id & & 3 \\
\hline D11S2260E ${ }^{2}$ & 11 & c-0cf09 & F01755 & no id & & 3 \\
\hline D11S2261E & 11 & c-0ch08 & Z38477 & no id & & 3 \\
\hline D11S2262E & 11 & c-0da02 & Z38480 & no id & & 24 \\
\hline D11S2263E & 11 & c-0ed05 & $Z 38520$ & no id & & 15 \\
\hline D11S2264E & 11 & c-0gf10 & F01880 & no id & & 19 \\
\hline D11S2265E & 11 & c-0me10 & Z38713 & no id & & 3 \\
\hline D11S2266E & 11 & c-0pa04 & Z38779 & no id & & 2 \\
\hline D11S2267E & 11 & $\mathrm{c}-0 \mathrm{pg} 04$ & F02133 & no id & & 21 \\
\hline D11S2268E & 11 & $c-0 q d 11$ & Z38820 & no id & & 3 \\
\hline D11S2269E & 11 & c-0sh09 & Z38906 & homol & $\begin{array}{l}\text { mouse flap } \\
\text { endonuclease-1 }\end{array}$ & 18 \\
\hline
\end{tabular}


HUMAN CHROMOSOME 11 NEW GENE TRANSCRIPIS

Table 1. (Continued)

\begin{tabular}{|c|c|c|c|c|c|c|}
\hline $\begin{array}{l}\text { eSTS } \\
\text { D numbers }\end{array}$ & $\begin{array}{l}\text { Chromosome } \\
\text { assignment }\end{array}$ & $\begin{array}{l}\text { Corre- } \\
\text { sponding } \\
\text { CDNA } \\
\text { clones }^{b}\end{array}$ & $\begin{array}{l}\text { EMBL } \\
\text { sequence } \\
\text { accession } \\
\text { number }\end{array}$ & Status ${ }^{c}$ & Gene product & Subregions \\
\hline $\mathrm{D} 11 \mathrm{~S} 2270 \mathrm{E}^{3}$ & 11 & c-0tg06 & Z38928 & no id & & 18 \\
\hline D11S2271E & 11 & c-0ug06 & Z38957 & no id & & 22 \\
\hline D11S2273E & 11 & c-Owa07 & Z38991 & no id & & 3 \\
\hline D11S2274E & 11 & $c-0 \times a 02$ & F02357 & homol & rat LL5 protein & 24 \\
\hline D11S2275E & 11 & $c-0 \times c 11$ & F04857 & no id & & 22 \\
\hline D11S2276E & 11 & $c-0 \times e 02$ & F02376 & no id & & 22 \\
\hline D11S2277E ${ }^{4}$ & 11 & $c-0 \times g 02$ & F02384 & no id & & 23 \\
\hline D11S2278E & 11 & $\mathrm{c}-0 \mathrm{zc} 01$ & Z39077 & no id & & 5 \\
\hline D11S2279E & 11. & c-0zg08 & Z39100 & no id & & 5 \\
\hline D11S2280E & 11 & $c-10 \mathrm{~b} 08$ & Z38142 & no id & & 12 \\
\hline D11S2283E & 11 & $\mathrm{C}-12 \mathrm{~h} 10$ & Z39175 & no id & & 16 \\
\hline D11S2284E & 11 & $c-13 e 12$ & Z39199 & no id & & 23 \\
\hline D11S2286E & 11 & $c-14 a 01$ & Z39212 & no id & & 21 \\
\hline D11S2287E & 11 & $c-15 b 10$ & Z39242 & no id & & 22 \\
\hline D11S2288E & 11 & $c-17 c 12$ & F02702 & no id & & 19 \\
\hline D11S2289E ${ }^{1}$ & 11 & $c-17 e 02$ & Z39328 & no id & & 19 \\
\hline D11S2290E & 11 & $c-19 b 09$ & Z39395 & no id & & 18 \\
\hline D11S2291E & 11 & $c-19 f 07$ & Z39415 & no id & & 18 \\
\hline D11S2292E ${ }^{3}$ & 11 & $c-19 g 08$ & F02763 & no id & & 18 \\
\hline D11S2293E & 11 & $c-1$ ag04 & Z39462 & no id & & 23 \\
\hline D11S2294E & 11 & c-1ah07 & F02791 & no id & & 23 \\
\hline D11S2313E & 11 & c-zph05 & Z41301 & no id & & 25 \\
\hline D11S2314E & 11 & c-0de01 & Z42258 & no id & & 22 \\
\hline D11S2316E & 11 & $c-01$ e10 & Z42491 & no id & & 16 \\
\hline D11S2317E & 11 & c-Ona10 & F05806 & no id & & 24 \\
\hline D11S2318E & 11 & c-0pa09 & Z42603 & no id & & 24 \\
\hline D11S2319E & 11 & $c-0 \times f 10$ & Z42911 & no id & & 18 \\
\hline D11S2320E & 11 & c-0ya09 & Z42924 & no id & & 22 \\
\hline $\mathrm{D} 11 \mathrm{~S} 2321 \mathrm{E}^{2}$ & 11 & C-0ya12 & Z42925 & no id & & 3 \\
\hline D11S2322E & 11 & $c-10 c 09$ & Z42994 & no id & & 15 or 16 \\
\hline D11S2323E & 11 & $c-13 e 02$ & Z43105 & no id & & 12 \\
\hline D11S2325E & 11 & $c-1 \mathrm{aa} 05$ & Z46134 & no id & & 22 \\
\hline D11S2329E & 11 & c-zpe07 & Z45606 & no id & & 22 \\
\hline D11F194S1E & $11 / 9$ & b-b0d01 & F01190 & id & hemoglobin beta & 1 \\
\hline D11F217S1E & $11 / 4$ & $c-13 c 10$ & Z39189 & no id & & 17-19 \\
\hline D11F223S1E & $11 / 12$ & $c-17 d 03$ & Z39321 & no id & & 15 or 16 \\
\hline D11F231S1E & $11 / 7$ & c-zrf04 & $Z 41357$ & rel & $\begin{array}{l}\text { human DNA J protein } \\
\text { homolog HSJ1 }\end{array}$ & $\begin{array}{l}1,21, \text { or } \\
22\end{array}$ \\
\hline D11F241S1E & $11 / 19$ & c-0kf07 & F05736 & rel & $\begin{array}{l}\text { mouse substrate of } \\
\text { protein tyrosine } \\
\text { kinase receptors } \\
\text { and p60v-src }\end{array}$ & 17 \\
\hline D11F250S1E & $11 / 13$ & c- 0 yc08 & Z42934 & no id & & 1,2 , or 3 \\
\hline D11F271S1E & $11 / 12$ & b-15h06 & Z28463 & no id & & 20 \\
\hline D11F278S1E & $11 / 12$ & b-37h03 & Z19512 & no id & & 3 \\
\hline
\end{tabular}




\section{ROSIER ET AL.}

D11F241S1E and D11F231S1E to sequences related to the mouse substrate of protein tyrosine kinase receptors or p60v-src and human DNA J protein homolog HSJ1, respectively. Taking into account the 7 known genes and the fact that 9 markers are derived from four transcripts, the 80 eSTS markers tested define 68 new human gene transcripts.

\section{Regional Localization of the eSTS Markers on Chromosome II}

The 80 eSTS markers were tested on the DNA from a panel of 25 somatic cell hybrid lines, each containing different deletions of chromosome 11 (Couillin et al. 1994; van Heyningen and Little 1995). PCR assays enabled us to distribute the 80 eSTS markers among the different subregions all along chromosome 11 (Fig. 1; Table 1). The Mar57 and Lev55.3 lines allowed assignment of 25 and 54 eSTS markers on the short and long arms of chromosome 11, respectively, a distribution that reflects their physical length (58 and 86 Mb.) Ambiguous localization (see below) of eSTS marker D11F231S1E hindered its assignment to a specific area of chromosome 11 . The panel of somatic cell hybrids originally delineated 24 subregions. An additional subregion (Fig. 1, subregion 19) was defined here by five eSTS markers (D11S2245E, D11S2256E, D11S2264E, D11S2288E, and D11S2289E) that are present in the Lev55.3 line but absent in both G35F1a and CF5246. Thus, these eSTS markers distinguished breakpoints in the G35F1 and CF5246 somatic hybrid cell lines that could not be differentiated with markers reported previously (Couillin et al. 1994). According to these data our panel now difines 25 subregions, 16 on the short arm and 9 on the long arm of chromosome 11. This biased distribution is related to the fact that the panel was constructed primarily when studying the genetic disorders implicating the $11 \mathrm{p} 13-11 \mathrm{p} 15$ region (Wilms' tumor, WAGR syndrome). Correspondence between our subregions and the intervals defined previously (van Heyningen and Little 1995) can be deduced easily from common breakpoints and microsatellite markers.

Validation of our procedure is provided by the concordant localization of five eSTS markers (D11S2241E, D11S2242E, D11S2244E, D11S2245E, and D11F194S1E) corresponding to known transcripts already mapped within chromosome 11 . The sixth and seventh known gene transcripts encoding acidic ribosomal phosphoprotein P2 and small nuclear ribonucleotide polypeptide $C$ are now assigned to subregion 1 and 21 , respectively, of chromosome 11 (Fig. 1)

\section{Ambiguous Localizations}

Among the 80 assigned eSTS markers, 7 could not be assigned unambiguously to a unique subregion (Table 1). We assigned D11S2322E to the short arm of chromosome 11 but could not distinguish between subregions 15 and 16 because the hamster control was positive, thus preventing us from interpreting the results obtained with the hamster-derived lines and particularly with the G35Fla line. Other ambiguities came from multiassignment of the eSTS markers or/and from the ambiguous results obtained with some hybrid cell lines. D11F217S1E, D11F2231E, and D11F231S1E have been assigned to other chromosomes in addition to chromosome 11. (see Table 1). Owing to the presence of these chromosomes in some of our nonmonochromosomal somatic cell hybrids, none of these three eSTS markers could be assigned to a unique subregion. Some eSTS markers gave an ambiguous response with more than one hybrid cell line, impairing interpretation of the results. For example, D11S2252E does not amplify DNA from the LHV1PS or LHV1PH lines; D11S2257E amplifies DNA from neither of these two lines nor from the STO28, Pel40, or Pel16 lines. Localization of D11F250S1E presents the two difficulties mentioned above, multiassignment to chromosomes 11 and 13 and ambiguous responses with the STO28, Pel40, and Pel16 lines.

\section{A Resource of Potential Candidate Genes for Orphan Pathologies}

Correlation between the so-created genic map and the orphan disease map of chromosome 11 is schematized in Figure 1. Assignment of genetic disorders to given cytogenetic intervals (van Heyningen and Little 1995; GDB) makes it possible to delineate the subregions of our somatic cell hybrid panel involved in these pathologies. The number of potential candidate genes is given in Table 2 for the 31 orphan pathologies associated with chromosome 11 . The genes coding for acidic phosphoriboprotein P2 and small nuclear ribonucleotide polypeptide $\mathrm{C}$ have been in- 
cluded in the calculation because they were localized in this study and may not have been considered earlier as candidate genes for diseases associated with subregions 1 and 21. (Fig 1; Table 2).
HUMAN CHROMOSOME 11 NEW GENE TRANSCRIPIS

Localization of Two eSTS Markers within a YAC Contig at $11 p 13$

A 1.7-Mb YAC contig carrying the human BDNF gene has been constructed and integrated into
DISEASE MAP

ORPHAN DISEASES

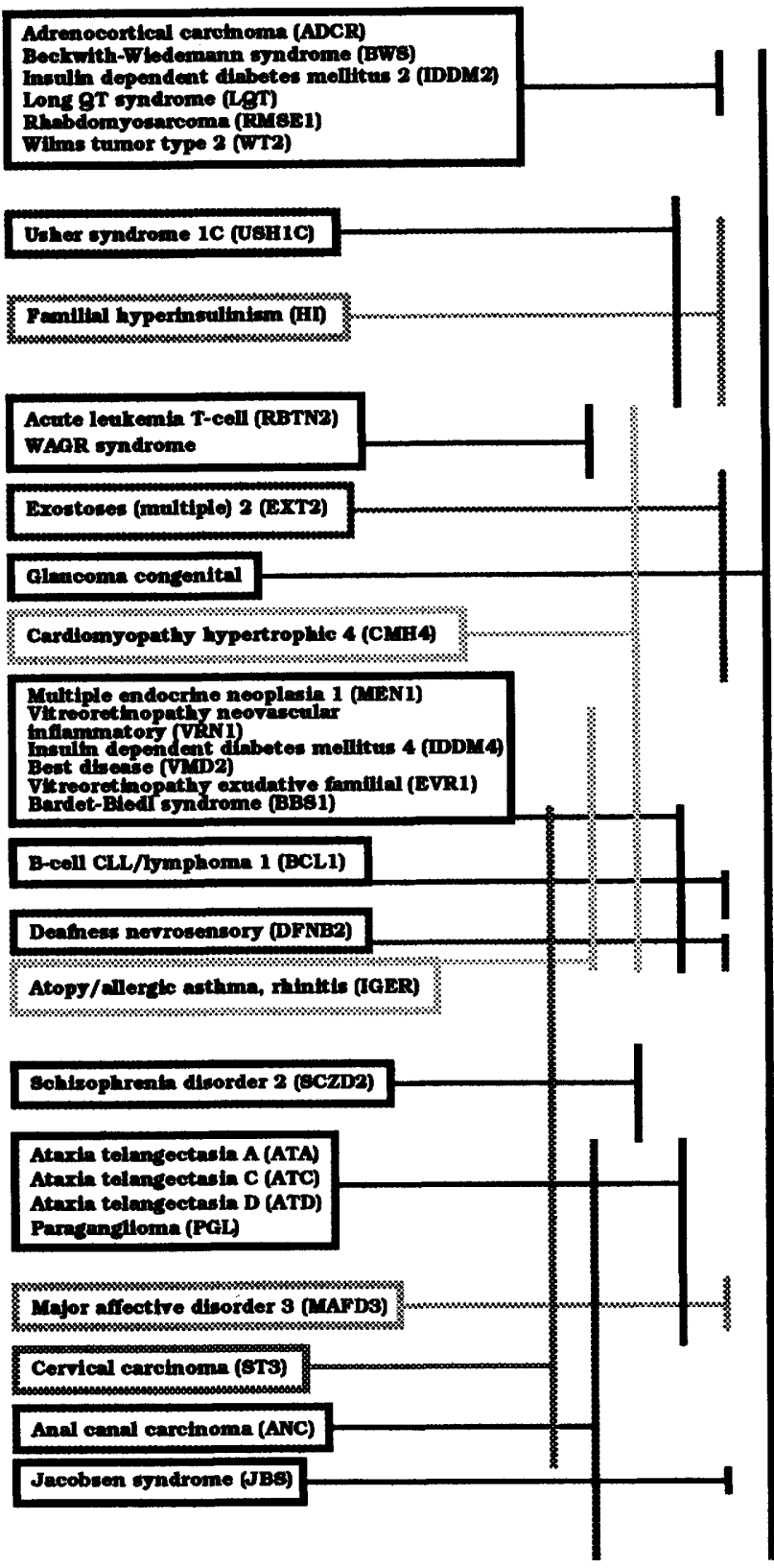

CYTOGENETIC

\section{CHROMOSOME 11}

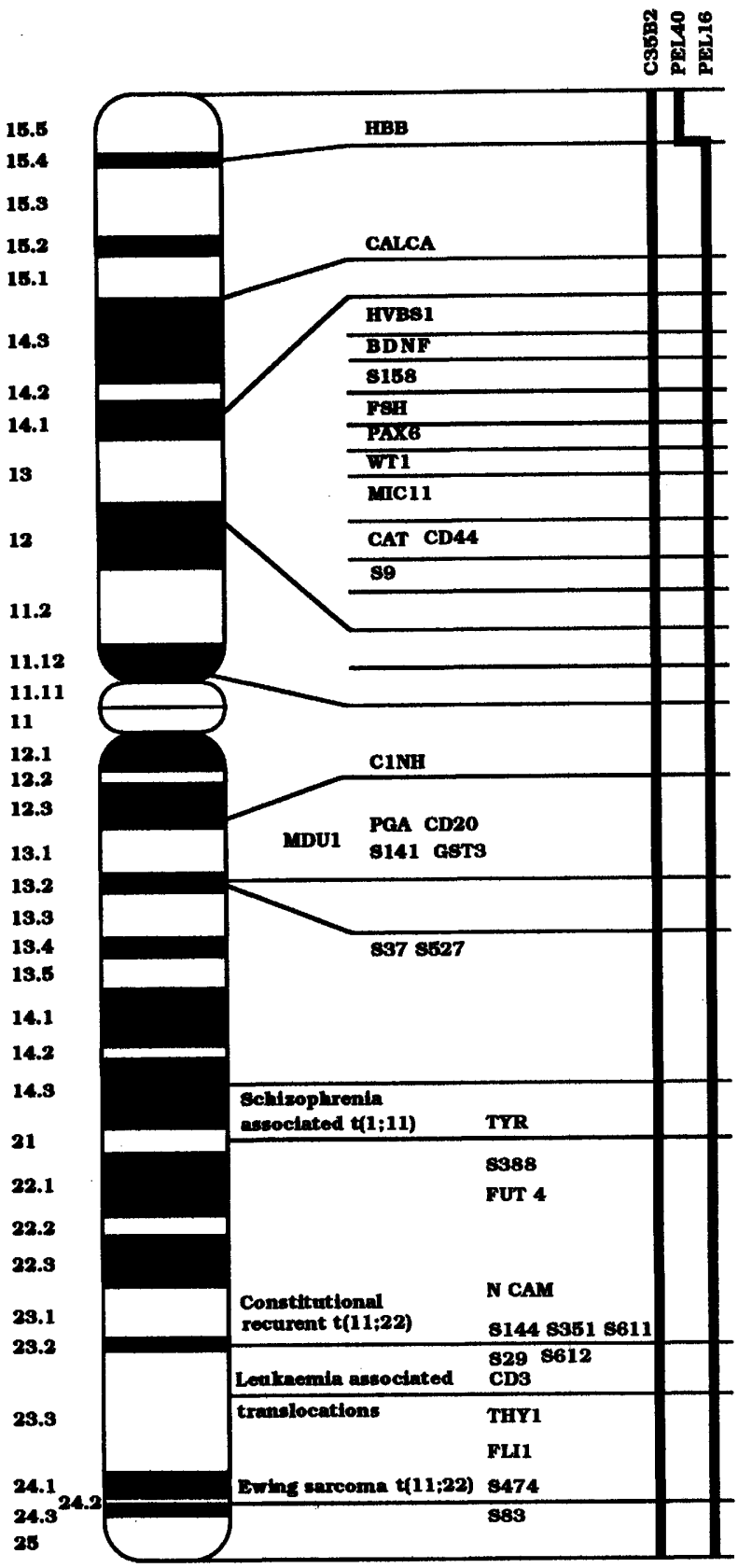

Figure 1 (Fig. 1 and legend continued on following page.) 
ROSIER ET AL.

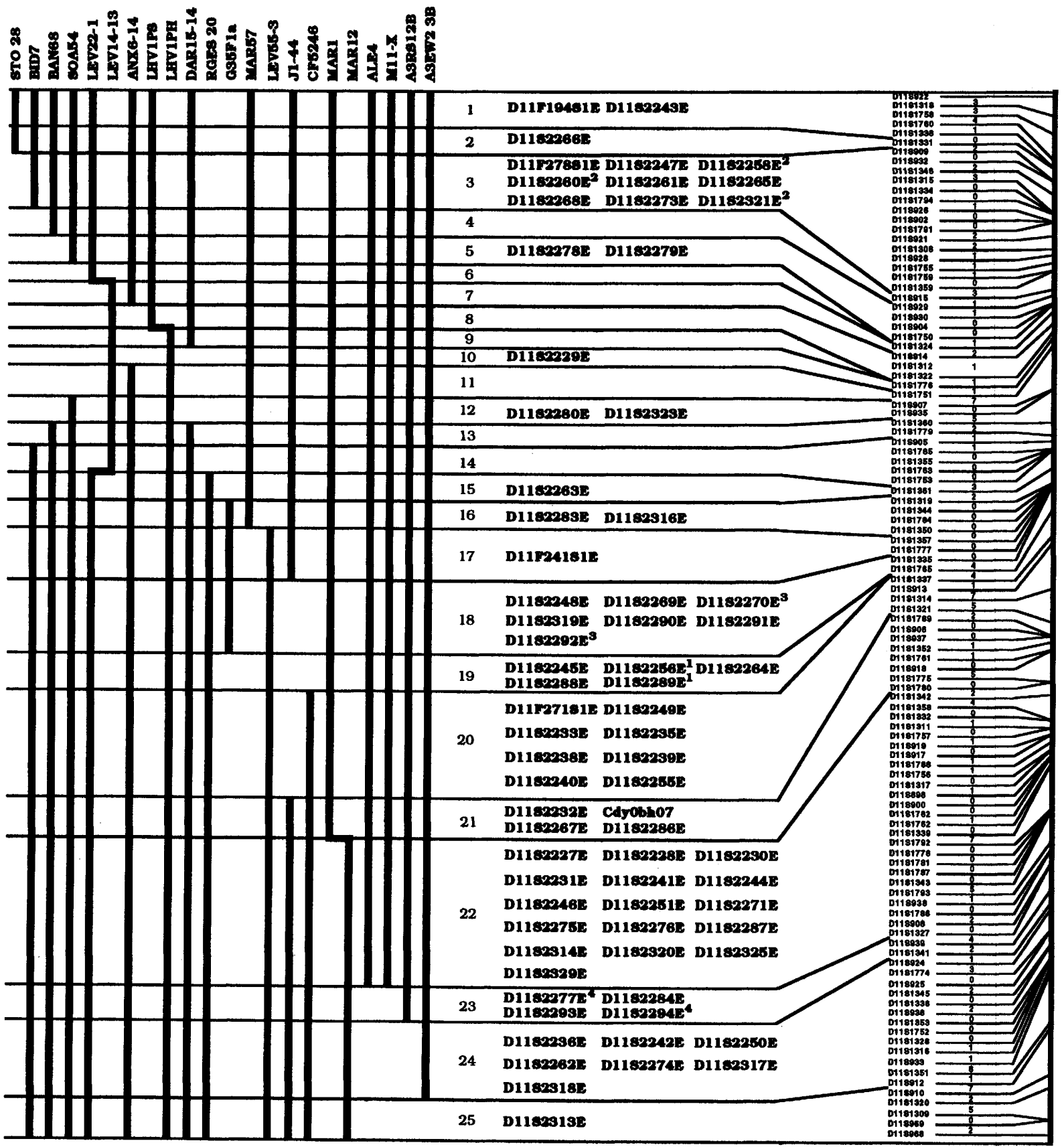

Figure 1 Integrated view of the disease, cytogenetic, genic, and genetic maps of chromosome 11. (Disease map) Orphan pathologies are listed at left. Diseases associated with the same cytogenetic interval are boxed. The cytogenetic localization of each group is represented by vertical lines linked to the corresponding boxes. (Cytogenetic map) Bold, vertical lines indicate the portion of human chromosome 11 that each hybrid cell line contains. The hybrid cell panel divides chromosome 11 into 25 intervals illustrated by horizontal lines. (Genic map) In each subregion, the tested ESTS markers are displayed in alphabetical and numerical order, with no implication about physical order. The eSTS markers that are derived from transcripts of the same gene (cDNA families) are indicated by numbers. (Genetic map) Shown are the best-supported order for 107 microsatellite markers (4: S. Fauré and J. Weissenbach, pers. comm.). The genetic position of each microsatellite on chromosome 11 is schematized at right by lines. 
HUMAN CHROMOSOME 11 NEW GENE TRANSCRIPIS

Table 2. List of orphan pathologies localized on chromosome 11 and number of potential candidate genes

\begin{tabular}{|c|c|c|c|}
\hline Orphan pathologies & $\begin{array}{l}\text { Cytogenetic } \\
\text { localization }\end{array}$ & $\begin{array}{l}\text { Subregion } \\
\text { concerned }\end{array}$ & $\begin{array}{l}\text { Number of new } \\
\text { potential } \\
\text { candidate genes }\end{array}$ \\
\hline Adrenocortical carcinoma & $11 \mathrm{p} 15.5$ & 1 & 4 \\
\hline Beckwith-Wiedemann syndrome & $11 \mathrm{p} 15.5$ & 1 & 4 \\
\hline Insulin-dependent diabetes mellitus & $11 \mathrm{p} 15.5$ & 1 & 4 \\
\hline Long QT syndrome & $11 \mathrm{p} 15.5$ & 1 & 4 \\
\hline Rhabdomyosarcoma & $11 \mathrm{p} 15.5$ & 1 & 4 \\
\hline Wilms tumor type 2 & $11 \mathrm{p} 15.5$ & 1 & 4 \\
\hline Usher syndrome 1C & 11p15.2-p14 & 2-14 & 16 \\
\hline Familial hyperinsulinism & 11p15.1-p14 & $2-14$ & 16 \\
\hline Acute leukemia T-cell & $11 \mathrm{p} 13$ & $5-14$ & 5 \\
\hline WAGR syndrome & $11 \mathrm{p} 13$ & $5-14$ & 5 \\
\hline Cardiomyopathy hypertrophic 4 & $11 \mathrm{p} 13-q 13$ & $5-20$ & 31 \\
\hline Exostoses (multiple) 2 & $11 \mathrm{p} 12$-cen & $5-17$ & 14 \\
\hline Atopy/allergic asthma, rhinitis & $11 q 12-q 13$ & $17-20$ & 19 \\
\hline B-cell CLL/lymphoma 1 & $11 q 13.3$ & 20 & 8 \\
\hline Deafness neurosensory & $11 \mathrm{q} 13.5$ & 20 & 8 \\
\hline Bardet-Biedl syndrome & $11 q 13$ & $18-20$ & 18 \\
\hline Best disease & $11 \mathrm{q} 13$ & $18-20$ & 18 \\
\hline Insulin dependent diabetes mellitus 4 & $11 q 13$ & $18-20$ & 18 \\
\hline Multiple endocrine neoplasia 1 & $11 q 13$ & $18-20$ & 18 \\
\hline Vitreoretinopathy exudative familial & $11 q 13$ & $18-20$ & 18 \\
\hline Vitreoretinopathy neovascular inflmmatory & $11 \mathrm{q} 13$ & $18-20$ & 18 \\
\hline Cervical carcinoma & $11 q 13-q 23$ & $18-24$ & 46 \\
\hline Schizophrenia disorder 2 & $11 q 14-q 21$ & $20-22$ & 27 \\
\hline Ataxia telangiectasia A, C, D & $11 q 22-q 23$ & $22-24$ & 24 \\
\hline Paraganglioma & $11 q 22-q 23$ & $22-24$ & 24 \\
\hline Anal canal carcinoma & 11q22-qter & $22-25$ & 25 \\
\hline Major affective disorder 3 & $11 \mathrm{q} 23.1$ & 22 & 15 \\
\hline Jacobsen syndrome & $11 \mathrm{q} 24.1$ & 24 & 6 \\
\hline Glaucoma congenital & 11 & $1-25$ & 70 \\
\hline
\end{tabular}

the physical, cytogenetic, and genetic maps of chromosome 11 (Rosier et al. 1994). It constitutes a basis for the isolation and characterization of genes located within this chromosomal region that may be involved in the WAGR syndrome and, more precisely, in the mental retardation phenotype associated with this syndrome. As the BDNF gene maps to subregion 6 , there were only two eSTS markers (D11S2278E and D11S2279E) present in the neighboring subregion 5 that could be tested on the four YACs $(245 \mathrm{~F} 2$, $886 \mathrm{H} 12,892 \mathrm{C} 12,878 \mathrm{D} 5)$ of the contig. D11S2279E was found to map on the contig, being positive with YAC 892C12 but not with YACs 245F2, 886 H12, and 878D5, as expected, as these YACs do not extend over subregion 5 . We thus colocalized D11S2279E with the microsatellite marker D11S904 between the YAC end STSs D11S1568 and D11S1566, respectively. In addition, D11S2278E, which did not map to any of the four YACs but is assigned to subregion 5, could thus be localized between the telomeric boundary of this subregion and the YAC end STS D11S1568 together with the microsatellite markers D11S929 and D11S930 (Fig. 2).

\section{DISCUSSION}

The 80 assigned eSTS markers are distributed throughout chromosome 11-25 (31\%) on the short arm, $54(67 \%)$ on the long arm, with the remaining marker presenting an ambiguous lo- 


\section{ROSIER ET AL.}

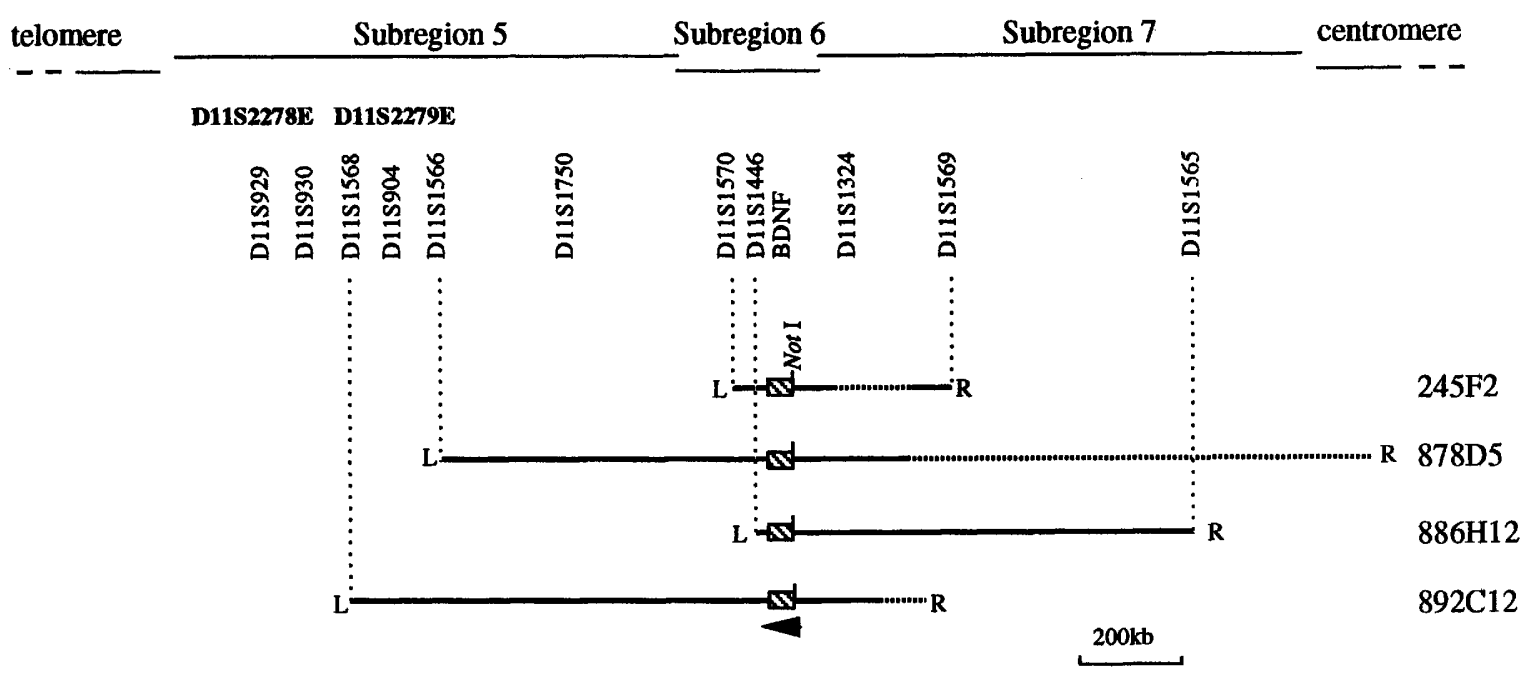

Figure 2 Refinement of the localization of two eSTS markers assigned to the vicinity of the BDNF gene with respect to the YAC contig at $11 \mathrm{p} 13$. Horizontal lines at the top cover the subregions defined by the hybrid cell lines beneath them. The names of the two eSTS markers are in boldface type at their approximate new localizations. The contig consists of four YACs named at right and depicted by horizontal lines. The approximate length of the chimeric parts is indicated by a dotted line. (L, R) Left and right arms, respectively, of the pYAC4 vector. Vertical dotted lines point out to the D numbers of STS markers obtained from each YAC extremity. The BDNF gene is represented by a box, and the Notl site by a short vertical line. The orientation of the BDNF gene (arrow) is indicated, as well as the D number of the microsatellite markers present in the different YACs and subregions.

calization (see Table 1). This distribution is similar to that observed either with known genes or with Généthon microsatellite markers on chromosome 11 (Gyapay et al. 1994; GDB) pointing out that $\mathrm{p}: \mathrm{q}$ distribution of all markers assigned until now to this chromosome is in the proportion 1:2.

The localization of five eSTS markers corresponding to five of the seven known gene transcripts is in agreement with data available in the GDB. This represents a good validation of our mapping strategy. Moreover, the sixth and seventh genes, coding for acidic ribosomal phosphoprotein P2 and small nuclear ribonucleotide polypeptide $\mathrm{C}$, respectively, have been newly localized in the 11p15.4-p15.5 and 11q14.3-q21 intervals, respectively. Among the 73 remaining eSTS markers, 4 correspond to cDNA sequences presenting similarities to known sequences and 69 to cDNA sequences with no putative identification, 9 of which can be clustered into families of overlapping sequences corresponding to four distinct human gene transcripts (R. Houlgatte, $R$. Marriage-Samson, S. Duprat, A. Tessier, S. Bentolila, B. Lamy, and C. Auffray, in prep.). In summary, the homologous, related, and unknown cDNAs appear to be derived from 68 new human gene transcripts that are now physically linked to known polymorphic markers. This represents more than a threefold increase in the number of unknown gene transcripts regionalized on chromosome 11 (van Heyningen and Little 1995). We assume that the corresponding chromosomal sites contain functional genes, but as the possibility exists that some of them might be pseudogenes, this has to be confirmed by genomic sequencing. Further cDNA sequence clustering analysis should also help in assessing the actual number of genes mapped in this study.

All orphan pathologies linked to chromosome 11 are listed and localized in Figure 1 (van Heyningen and Little 1995; disease map; GDB) and are defined by cytogenetic intervals. One exception is glaucoma, which is associated with the entire chromosome 11 . Most assigned eSTS markers presented here are now mapped to an integrated cytogenetic and genetic map including 107 microsatellite markers developed by Généthon (Fig. 1; Couillin et al. 1994; S. Fauré and J Weissenbach, pers. comm.). D11S2279E has been mapped further onto one YAC, 892C12 (Fig. 2). The number of potential candidate genes for a given gene disorder depends on its precise localization (Table 2). For example, candidate genes 
for glaucoma should be searched among all 70 gene transcripts ( 68 unknown and 2 known but previously not assigned) newly regionalized to chromosome 11 . In contrast, for the Jacobsen Syndrome localized to 11q24.1, only six gene transcripts should be considered as possible candidates.

D11S2278E and DS11S2279E have been mapped close to the BDNF gene. This region between FSHB and HBVS1 (Fig. 1) has been proposed previously to contain a locus specific for the WAGR mental retardation phenotype on the basis that individuals with deletions extending into this interval are mentally retarded, whereas those with deletions breaking proximal to it are not (Hanson et al. 1992). Thus, the two gene transcripts mapping to this region are potential candidates for the mental retardation phenotype associated with this complex pathology. Their involvement in the disease can now be assessed by comparison of expression and DNA sequence between normal and affected individuals. The availability of eSTS markers will facilitate RT-PCR assays and further screening of cDNA libraries to isolate full-length clones.

This work represents a contribution toward a complete and high resolution genic map of chromosome 11. It will be complemented by assignment of the eSTS markers using radiation hybrid panels and/or cloned DNA fragments to obtain further integration with the genetic and physical maps of chromosome 11. Additional eSTS markers are steadily being produced and integrated into the genic map and will continuously increase its coverage and the likelihood that the genes involved in specific physiological or pathological traits will have been cataloged, thereby validating the usefulness of this resource for their identification.

\section{METHODS}

\section{Somatic cell hybrids and YAC contig}

A panel of 25 somatic hybrid cell lines from different origins was used for this study. The main characteristics and references (human parental subjects, first characterization, and mapping data) are described by Couillin et al. (1994), with the exception of the ST028 line, which derives from patient STO 46,XY,t(1;11)(q11;p15.5) (S. Gilgenkrantz, unpubl.) and retains der(1). All hybrids were obtained by fusion between human and mouse cells except for the C35B2, G35F1a, and J1-44 lines, which are derived from hamster cells. The fragments of chromosome 11 present in each of these 25 hyprid lines and the subregions delineated with the whole panel are schematized in Figure 1.
The number of subregions depends directly on the number and type of rearrangements, for example, an interstitial deletion defines two breakpoints. The subregions were characterized by cytogenetic data and reference markers. All hybrid lines were typed with 107 microsatellite markers developed by Généthon, allowing the integration of the cytogenetic and genetic maps.

YAC clones $245 \mathrm{~F} 2,886 \mathrm{H} 12,892 \mathrm{C} 12$, and $878 \mathrm{D} 5$ belonging to a $1.7-\mathrm{Mb}$ contig established at $11 \mathrm{p} 13$ around the BDNF locus are presented in Figure 2 (Rosier et al. 1994). Three negative control DNAs were used: DNA from mouse and hamster extracted from SP2 and CHO cell lines, respectively (Couillin et al. 1994), and DNA from Saccharomyces cerevisiae (Promega).

\section{eSTS Markers}

eSTS markers were designed from a collection of partial cDNA sequences derived from cDNA libraries from human skeletal muscle (Stratagene no. 936216) or infant brain (Soares et al. 1994). The D numbers of all eSTS markers used here are listed in Table 1. The eSTS markers have been assigned previously to chromosome 11 using a panel of nonochromosomic somatic cell hybrids and multiassignments verified with a panel of multichromosomic somatic cell hybrids (Auffray et al. 1995).

\section{PCR on Somatic Cell Hybrid and YAC DNA}

Primers synthesized by Genset, Genosys, or DNAgency were from the same batches as those used for initial chromosomal assignment. Amplification conditions for all primer pairs used were as follows. Reaction mixtures (50 $\mu \mathrm{l})$ containing $400 \mathrm{ng}$ of DNA except for human genomic DNA (Clontech, $50 \mathrm{ng}$ ), 25 pmoles of each oligonucleotide primer, $0.2 \mathrm{~mm}$ dNTPs, and $2 \mathrm{~mm} \mathrm{MgCl}_{2}$ were incubated with 1.5 units of AmpliTaq DNA polymerase (Perkin-Elmer Cetus) under standard ionic conditions. Cycling was as follows: $5 \mathrm{~min}$ at $94^{\circ} \mathrm{C} ; 30$ cycles composed of $30 \mathrm{sec}$ at $94^{\circ} \mathrm{C}, 30 \mathrm{sec}$ at $59^{\circ} \mathrm{C}$, and $30 \mathrm{sec}$ at $72^{\circ} \mathrm{C}$ using the GeneAmp PCR System 9600 (Perkin-Elmer Cetus). Amplification products were analyzed by electrophoresis on a $3 \%$ agarose gel (NuSieve, FMC) in 1× TBE (90 mM Tris, $90 \mathrm{~mm}$ boric acid, 2 mM EDTA at $\mathrm{pH} 8$ ) and visualized with ethidium bromide under UV light.

\section{ACKNOWLEDGMENTS}

We thank Veronica van Heyningen for providing the DNA of the M11X, Mar 12, Mar 1, and J1-44 somatic cell hybrids, Olivier Delattre for providing the somatic cell hybrid Ale 4, and Sabine Fauré and Jean Weissenbach for communicating the most recent data from the Généthon microsatellite genetic map of chromosome 11 . We are also grateful to Rémi Houlgatte for providing sequence analysis information and to Nicolas Vignier, Alexandra Kobetz, Bernard Prudhon, Frédéric Lorenzo, and the Genexpress Program team at Généthon for technical assistance and advice. The Genexpress Program is supported by CNRS, Association Française contre les Myopathies (AFM), and grants from Ministère de l'Enseignement Supèrieur et de la Recherche (MESR), Groupement de Recherches et d'Etudes 


\section{ROSIER ET AL.}

sur les Gènomes (GREG), and the European Union Biomed 1 Program to C.A. M.-F.R. and I.R-A. are recipients of a research allocation from MESR.

The publication costs of this article were defrayed in part by payment of page charges. This article must therefore be hereby marked "advertisement" in accordance with 18 USC section 1734 solely to indicate this fact.

\section{REFERENCES}

Antequera, F. and A. Bird. 1994. Predicting the number of human genes. Nature Genet. 8: 114 .

Auffray, C., G. Béhar, F. Bois, C. Bouchier, C. Da Silva, M.D. Devignes, S. Duprat, R. Houlgatte, M.N. Jumeau, B. Lamy, F. Lorenzo, H. Mitchell, R. Mariage-Sanson, G. Piétu, Y. Pouliot, C. Sébastiani-Kabaktchis, and A. Tessier. 1995. IMAGE: Integrated molecular analysis of the human genome and its expression. C.R. Acad. Sci. Ser. III Sci. vie 318: 263-272.

Chiannilkulchai, N., P. Pasturaud, I. Richard, C. Auffray, and J. Beckmann. 1995. A primary expression map of the chomosome $15 q 15$ region containing the recessive form of limb-girdle muscular dystrophy (LGMD2A) gene. Hum. Molec. Genet. 4: 717-725.

Couillin, P., E. Le Guern, A. Vignal, C. Fizames, N. Ravisé, D. Delportes, I. Reguigne, M.F. Rosier, C. Junien, V. van Heyningen, and J. Weissenbach. 1994. Assignment of 112 microsatellite markers to 23 chromosome 11 subregions delineated by somatic hybrids: Comparison with the genetic map. Genomics 21: $379-387$.

Cox, D., M. Burmeister, E. Price, S. Kim, and R. Myers. 1990. Radiation hybrid mapping: A somatic cell genetic method for constructing high-resolution maps of mammalian chromosomes. Science 250: 245-250.

Fields, C., M. Adams, O. White, and J.C. Venter. 1994. How many genes in the human genome? Nature Genet. 7: 345-346.

Gardiner, K. and R. Mural. 1995. Getting the message: Identifying transcribed sequences. Trends Genet. 11: $77-79$.

Gyapay, G., J. Morisette, A. Vignal, C. Fizames, P. Millasseau, S. Marc, G. Bernardi, M. Lathrop, and J. Weissenbach. 1994. The 1993-94 Généthon human genetic linkage map. Nature Genet. 7: 246-339.

Hanson, I., A. Seawright, and V. van Heyningen. 1992. The human BDNF gene maps between FSHB and HVBS1 at the boundary of 11p13-p14. Genomics 13: 1331-1333.

James, M., C. Richard III, J.-J. Schott, C. Yousry, K. Clark, J. Bell, J. Terwilliger, J. Hazan, C. Dubay, A. Vignal, M. Agrapart, T. Imai, Y. Nakamura, M. Polymeropoulos, J. Weissenbach, C. Cox, and G. Lathrop. 1994. A radiation hybrid map of 506 STS markers spanning human chromosome 11. Nature Genet. 8: 70-76.
Maisinpierre, P., M. Le Beau, R. Espinosa III, N. Ip, L. Belluscio, S. de la Monte, S. Squinto, M. Furth, and G. Yancopoulos. 1991. Human and rat brain-derived neurotrophic factor and neurotrophin-3: Gene structures, distributions, and chromosomal localizations. Genomics 10: $558-568$.

Morton, N. 1991. Parameters of the human genome. Proc. Natl. Acad. Sci. 88: 7474-7476.

Murray, J.C. 1994. A comprehensive human linkage map at centiMorgan density. Science 265: 2049-2054.

Polymeropoulos, M., H. Xiai, J.M. Sikela, M. Adams, J.C. Venter, and C.R. Merril. 1993. Chromosomal distribution of 320 genes from a brain cDNA library. Nature Genet. 4: 381-386.

Rosier, M.F., A.F. Goguel, A. Martin, D. Le Paslier, P. Couillin, R. Houlgatte, A. Bernheim, C. Auffray, and M.D. Devignes. 1994. A 1.7 Mb YAC contig around the human BDNF gene (11p13): Integration of the physical, genetic, and cytogentic maps in relation to WAGR syndrome. Genomics 24: 69-77.

Soares, M.B., M. de Fatima Bonaldo, P. Jelenc, L. Su, L. Lawton, and A. Efstratiadis. 1994. Construction and characterization of a normalized cDNA library. Proc. Natl. Acad. Sci. 91: 9228-9232.

van Heyningen, V. and P. Little. 1995. Report of the fourth international workshop on human chromosome 11 mapping 1994. Cytogenet. Cell Genet. 69: 128-158.

Withmore, S., S. Apostolou, S. Lane, J. Nancarrow, H. Phillips, R. Richards, G. Sutherland, and D. Callen. 1994. Isolation and characterization of transcribed sequences form a chromosome $16 \mathrm{hn}$-cDNA library and the physical mapping of genes and transcribed sequences using a high-resolution somatic cell panel of human chromosome. Genomics 20: 169-175.

Received June 15, 1995; accepted in revised form July 13, 1995. 


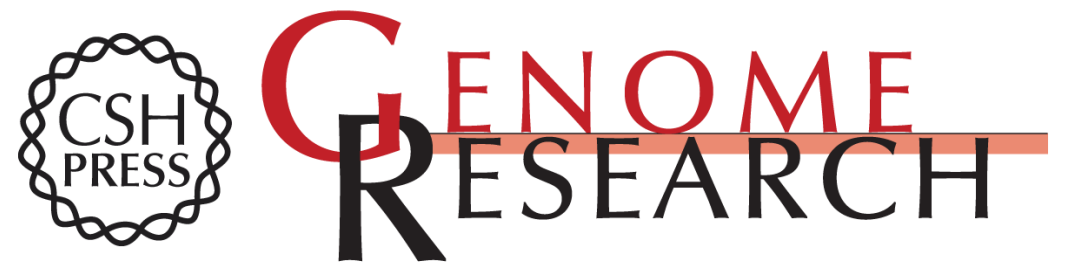

\section{Regional assignment of 68 new human gene transcripts on chromosome 11.}

M F Rosier, I Reguigne-Arnould, P Couillin, et al.

Genome Res. 1995 5: 60-70

Access the most recent version at doi:10.1101/gr.5.1.60

References This article cites 18 articles, 4 of which can be accessed free at:

http://genome.cshlp.org/content/5/1/60.full.html\#ref-list-1

\section{License}

Email Alerting Receive free email alerts when new articles cite this article - sign up in the box at the Service top right corner of the article or click here.

\section{Affordable, Accurate Sequencing.}

To subscribe to Genome Research go to:

https://genome.cshlp.org/subscriptions 